\title{
TAF13 wt Allele
}

National Cancer Institute

\section{Source}

National Cancer Institute. TAF13 wt Allele. NCI Thesaurus. Code C52600.

Human TAF13 wild-type allele is located in the vicinity of 1 p13.3 and is approximately 14

$\mathrm{kb}$ in length. This allele, which encodes transcription initiation factor TFIID subunit 13

protein, plays a role the mediation of promoter responses to various activator and repressor molecules. 